\title{
New Echinoid (Spatangoida: Toxasterinidae) from the Campanian of Coahuila, Northeastern Mexico
}

Luis E. Silva-Martínez, Alberto Blanco-Piñón, Jesús A. de León-González, Hidalgo Rodríguez-Vela

Luis E. Silva-Martínez

lesmartínez@hotmail.com

Alberto Blanco-Piñón

Hidalgo Rodríguez-Vela

Laboratorio de Paleobiología, Facultad de Ciencias Biológicas, Universidad Autónoma de Nuevo León, Av. Pedro de Alba y Manuel L. Barragán s/n, Ciudad Universitaria, San Nicolás de los Garza Nuevo León, México. C.P. 66455 .

Jesús A. de León-González

Laboratorio de Biosistemática, Facultad de Ciencias Biológicas, Universidad Autónoma de Nuevo León, UANL, Av. Universidad s/n, Ciudad Universitaria, San Nicolás de los Garza, Nuevo León, C.P. 66455,México.

\section{ABSTRACT}

Three specimens corresponding to a new echinoid species from the Upper Cretaceous (Lower Campanian) from Austin Formation in the northeastern of Mexico are reported here. The morphology of the specimens (test with a cordiform aboral region) as well as the sedimentary environment reported at the Austin Formation, suggests that this species represents an infaunal and detritivorous dweller living in a shallow water environment within the continental shelf. This is consistent with the more actual knowledge for other species of Diplodetus

Keywords: Echinoids, Diplodetus, Upper Gretaceous, Campanian, Austin Formation, NE Mexico.

\section{RESUMEN}

Se reportan tres especímenes de Diplodetus brisenoi, una nueva especie de equinoideo del Campaniano Inferior (Cretácico Superior) de la Formación Austin, en fiménez, Coahuila, noreste de México. Tanto su morfología (testa con ámbito cordiforme) como el ambiente de depósito reportado para la Formación Austin sugieren que esta especie representa un elemento de la infauna con hábitos detritivoros en ambientes de plataforma, lo cual es consistente con lo reportado para otras especiesdel género Diplodetus.

Palabras clave: Equinoideos, Diplodetus, Cretácico Superior, Campaniano, Formación Austin, NE de México. 


\section{Introduction}

The echinoid Diplodetus was described by Schlüter (1900) and currently contains eight formal species, represented by $D$. brevistella (Schlüter, 1899), D. parvistella (Schlüter, 1899), D. americanus (Stephenson, 1941), D. bucardium (Goldfuss, 1829), D. duponti (Lambert, 1911), D. nutrix (Lambert, in Boule, 1899), D. gauthieri (Cotteau, 1908); D. coloniae (Cotteau, 1877). This genus is also known in Upper Cretaceous rocks from Belgium (Jagt, 2000), Germany (Newman et al., 2000), Netherlands (Jagt, 2000), Spain (Rehfeld and Ernest, 1998) and it is less common from the Paleocene of Madagascar, Ukraine and Western Europe (Cotteau, 1877). In Mexico, the only known record for this genus was reported by Silva-Martínez et al. (2014) in outcrops of the Austin Formation (Lower Campanian: Upper Cretaceous), at the localities of Arroyo El Freno and Arroyo El Tecolote, in the municipality of Jiménez, Coahuila.

The present work provides a more detailed description of the specimens reported by Silva-Martínez (2014) in order to raise Diplodetus brisenoi as a new echinoid fossil species from Lower Campanian of Coahuila, Northeast of Mexico, and to give a short comment concerning its paleoecological significance within the Austin Formation at the study area.

In the collecting area (Figure 1), the Austin Formation consists in a section of at least $8 \mathrm{~m}$ of clayish limestone and calcareous marl, the last ones with a decimetric thickness (Figure 2 and Figure 3). The limestone shows a thickness that varies from 10 $\mathrm{cm}$ to $80 \mathrm{~cm}$, it exhibits a yellowish gray color in weathered samples or gray to light brown and occasionally dark brown in fresh samples. The limestone is characterized by the presence of a fine parallel lamination in a millimetric scale as well as the presence of pyrite nodules of more than 4 $\mathrm{cm}$ in diameter. The thickness of marl varies from 10 to $69 \mathrm{~cm}$ and exhibits a light gray coloration with yellowish tonalities in fresh samples, and gray bluish to green color in weathered samples. Some layers have reddish iron oxide bands whose thickness varies between of $3-4 \mathrm{~cm}$.

The marly sediments of the Austin Formation at Jiménez, Coahuila, hold up diverse fossil groups of fauna represented by several species of ammonoids, various genera of bivalves and echinoids, as well as one specimen of elasmobranchii and one specimen of a teleostean fish. Ammonoids are depicted by Bevahites internodosus, Fimenites cantusi, Delawarella delawarensis and Scaphites hippocrepis. Bivalves include ostreids of the genera Exogyra, Lopha and Gryphaea; as well as the inoceramids Cladoceramus undulatopliocatus and Inoceramus balticus. Echinoids are represented by Cidaris texanus, C. splendens, Salenia mexicana, Holectypus sp., Heteraster texanus, Diplodetus sp., Diplopodia hilli, Orthopsis casanovai, Micraster uddeni, Mecaster batnensis (Silva-Martínez et al., 2014). Fishes are represented by an Elasmobranchii of the genus Ptychodus (Hybodontoidei) and a Teleostean preliminary assigned to Goulmimichthys sp. (Figure 5).

In a previous work carried out by Vega et al. (2013) at Austin Formation, in the vicinity of the study area, he reported the presence of the ostreids Phrysaea (Gryphaea) aucella and Exogyra laeviscula, the ammonoid Parapuzosia boisei and two species of the genus Menabites as well as the crustacean (Decapoda) species Enoploclytia tepeyacensis.

According to Silva-Martínez et al. (2014) the presence of the ammonite Delawarella delawarensis (Morton, 1841) along the studied section supports the assignment of a Lower Campanian age for this unit.

\section{Methodology}

The specimens described in this work and assigned as Diplodetus brisenoi nov. sp. were collected from the section using traditional methods using a rock hammer and chisel. Subsequently they were labeled and transported to the Laboratorio de $\mathrm{Pa}$ leobiología, of the Facultad de Ciencias Biológicas, at Universidad Autónoma de Nuevo León for 


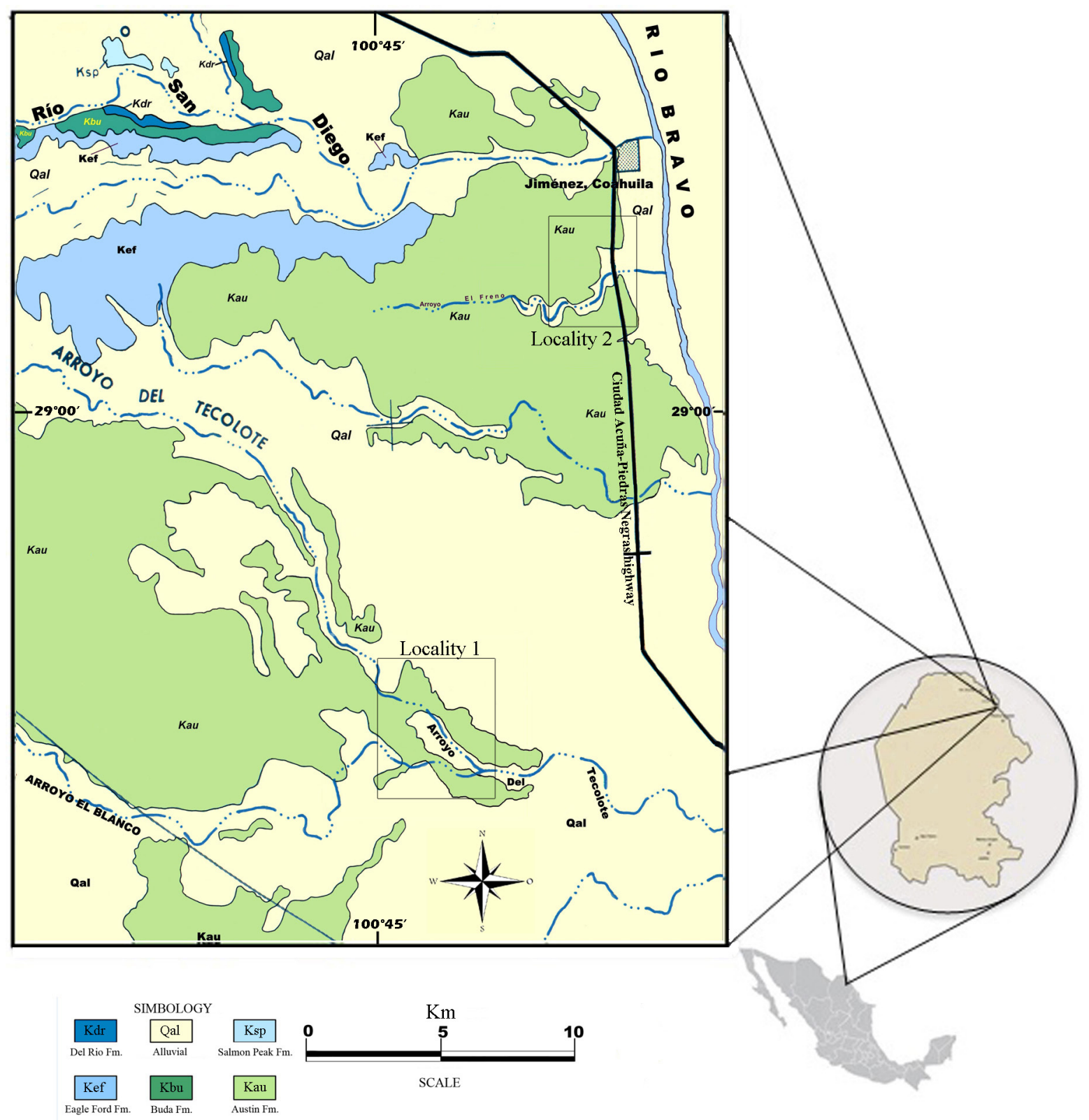

Figure 1 Localization map of the Austin Formation, the squares indicate the two sampling sites (Locality 1: Arroyo El Tecolote, Locality 2: Arroyo El Freno).

its study, documentation and housing as a part of the paleontological collection.

The specimens were mechanically and chemically prepared prior to its study. The mechanic preparation was conducted using a pneumatic engraving pen of variable speed in order to remove the covering rock. Afterwards, the chemical preparation consisted in placing the fossil material in a beaker and covers it with potassium hydroxide for at least
72 hours to dissolve the particles that remained after the mechanical preparation. Finally, the material was rinsed with tap water and let it dry. Once the paleontological material had been prepared, it was revised using a standard stereoscopic microscope LEICA-GME. The specimens were observed under different magnifications for its anatomical description and taxonomical determination according to the scientific literature criteria. 

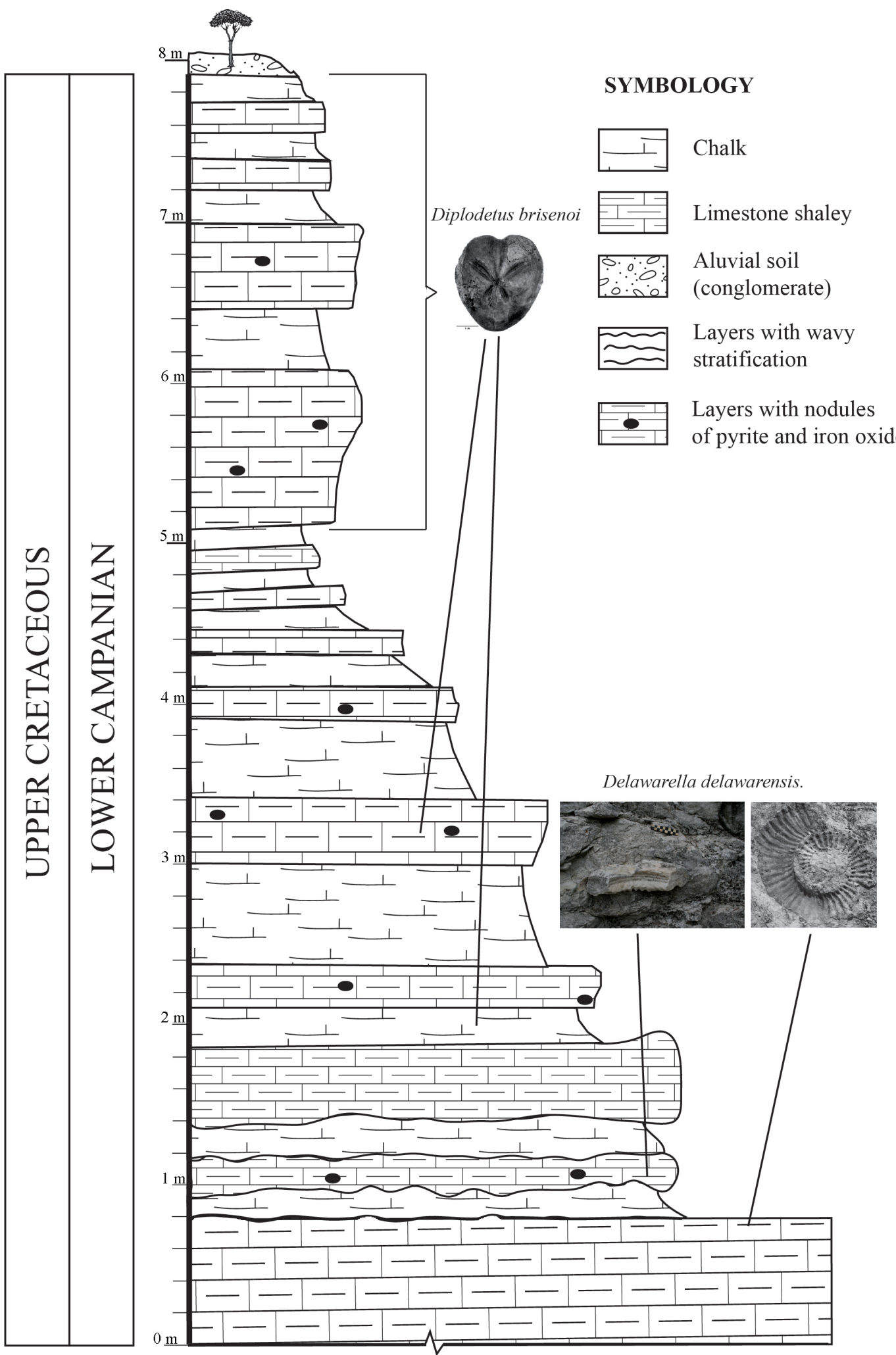

Figure 2 Stratigraphic profile and distribution of Diplodetus brisenoi nov. sp. at Arroyo El Freno, Jiménez, Coahuila. 


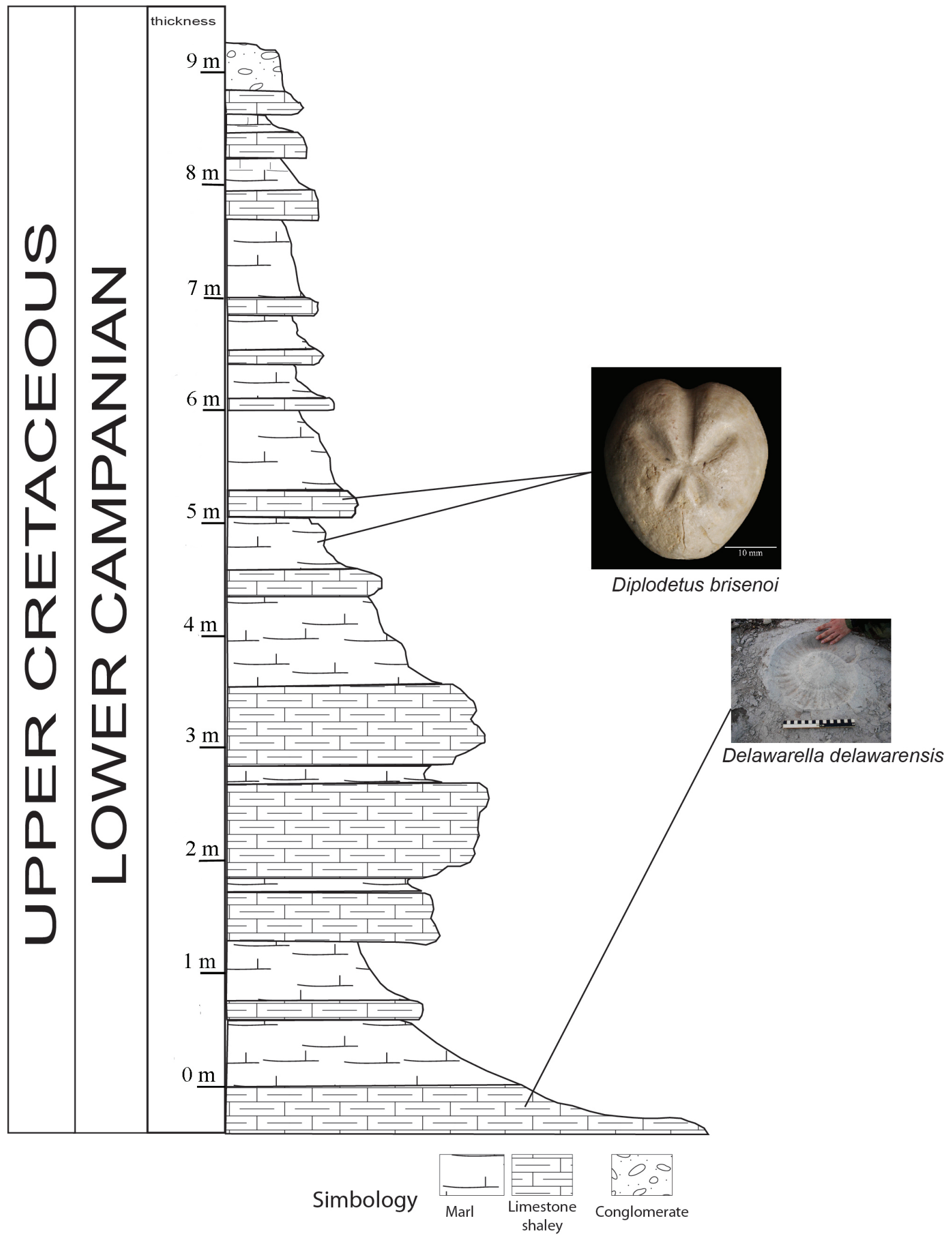

Figure 3 Stratigraphic profile of the Austin Formation at Arroyo El Tecolote, Jiménez, Coahuila, showing the vertical distribution of Diplodetus brisenoi nov. sp. 


\section{Systematical paleontology}

\author{
Order Spatangoida GLAUS, 1876 \\ Suborder Micrasterina Fischer, 1966 \\ Family Brissidae Gray, 1855 \\ Genus Diplodetus Schlüter, 1900 \\ Diplodetus brisenoi nov. sp. \\ (Figures 4 and 6)
}

Diagnosis. Test with the following characteristics: Length between 35.5 to $36.4 \mathrm{~mm}$. Width between 32 to $32.4 \mathrm{~mm}$, apical height 20.1 to 21.1 $\mathrm{mm}$, oval, cordiform, the lateral profile is higher in the posterior part of the apical system than in the anterior part. The last one is considerably more convex in contrast with the strongly truncated at the posterior part. Paired ambulacra petaloids, with pores in the fissure, the paired petals pores present equally size and form to the posterior ambulacra, which are short and sunken in a deep furrow. The odd ambulacra present oval pores separated by a pair of granules. The area of the test is rounded in its anterior part and truncated in the posterior part, with a elongated periproct supramarginal ended in tip in both edges, with a compact semi-ethmolytic apical system.

Holotype: FCBUANL_2458; Complete specimen with external visible characteristics.

Paratypes: FGBUANL_2454 and FGBUANL_2523; both specimens are complete with visible external characteristics.

Locus typicus: Arroyo El Freno and Arroyo El Tecolote, municipality of Jiménez, Coahuila, Northeastern Mexico.

Stratigraphic position: Austin Formation, Lower Campanian (Upper Cretaceous).

Derivatio nominis: Species name in honor to Professor Carlos Humberto Briseño de la Fuente for his important contribution to the invertebrate zoology in the Mexican state of Nuevo León and in the Northeastern of Mexico.

General Description. The echinoid specimens assigned to Diplodetus brisenoi from the Austin For- mation at Jiménez, Coahuila display a cordiform morphology with maximum length that varies from $35.5 \mathrm{~mm}$ to $36.4 \mathrm{~mm}$, width of $32.0 \mathrm{~mm}$ to $32.4 \mathrm{~mm}$ and a height between $20.1 \mathrm{~mm}$ and $21.1 \mathrm{~mm}$. Oval test with a cordiform outline, the anterolateral margins are rounded and the posterolaterals are almost straight, the width of the anterior third becomes narrower. The lateral profile is higher in the posterior part of the apical system than in the anterior part and it is considerably truncated at the back, the inferior surface is slightly convex.

The apical system becomes slightly eccentric towards the posterior part, with four genital gonoporesequally spaced, with a compact semi-ethmolytic apical system, with the posterior genital plates in contact with its posterior part of the madrepore plate, posterior ocellar plates in contact. Odd ambulacra (anterior) completely sunken; the pores of the petaliferus are short and in chevron pattern (inverted $\mathrm{V}$ ), each pair of pores is separated by a tiny tubercle (Figure 6). Paired petals are moderately sunken, the anterior pair is longer than the posterior pair, the first extends up to $2 / 3$ of margin and shows a divergent angle between 135 and 150 degrees, the posteriors are close to each other and depicting a divergent angle of 124 to 126 degrees (Figure 4D), the posterior petals pair extends up to the half of margin, pair-pore of the petals zone with a pair of transversally elongated pores and separated by four tubercles, pairpore of the petals zone as wider as the interpores. The peristome is small, subpentagonal and is located to $1 / 4$ of the anterior margin. The periproct is elongated, pointed in both endings and is in a supramarginal position, outstanding the truncated part of the test. It presents a peripetal fasciola.

\section{Dimenssions in milimeters}

$\begin{array}{cccc}\text { Specimen } & \text { Length } & \text { Width } & \text { Height } \\ \text { FCBUANL_2454 } & 35.7 & 32 & 21.1 \\ \text { FCBUANL_2458 } & 35.5 & 32.4 & 20.1 \\ \text { FCBUANL_2523 } & 36.4 & 32.2 & 20.2\end{array}$



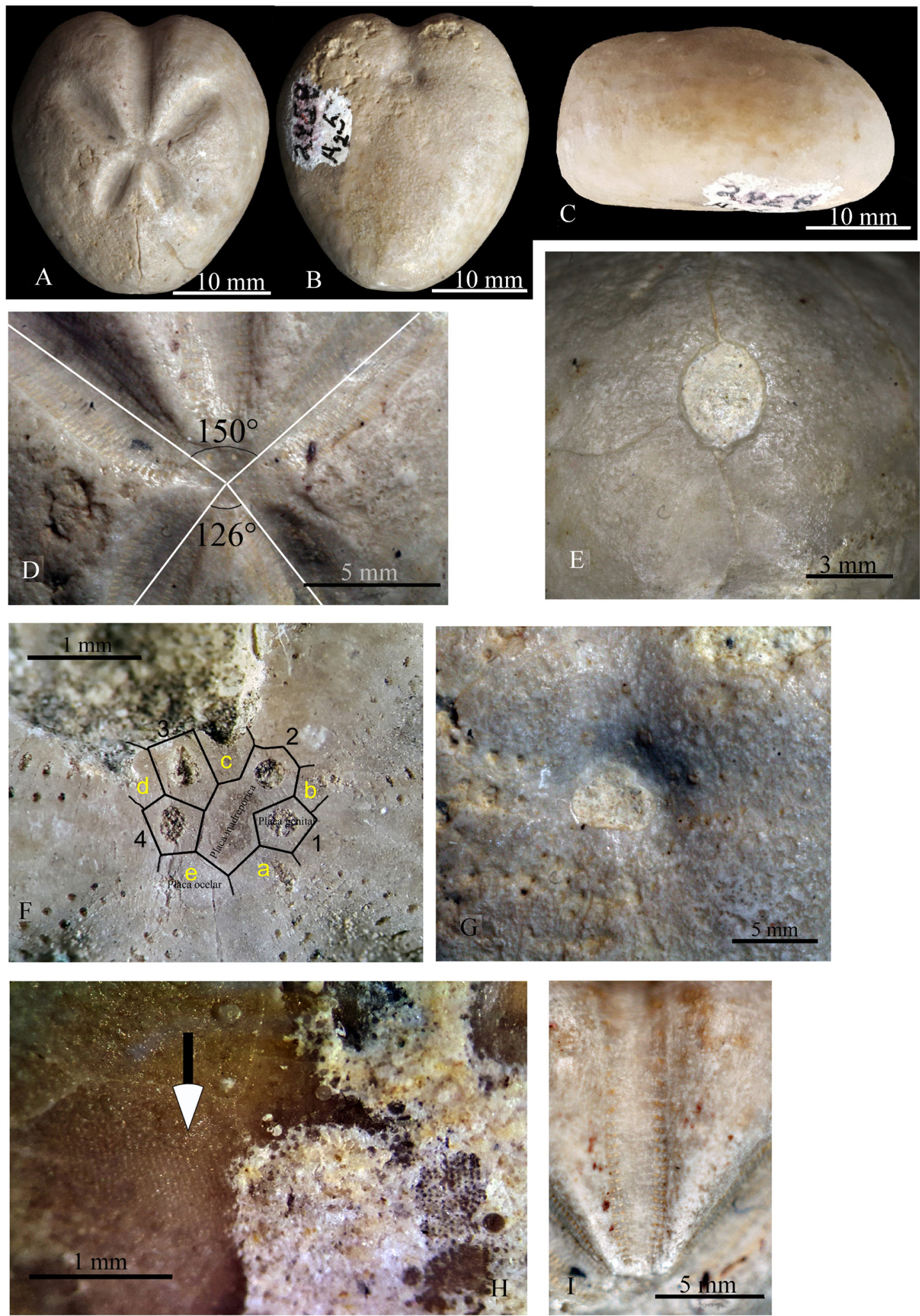

Figure 4 A: Diplodetus brisenoi nov. sp. Holotype FCBUANL_2458 apical, B: ventral view, C: lateral view, D: close-up of the apical system, E: view of the periproctal area, F: close-up of the apical system showing the arrangement of the genitals and ocellar plates (semiethmolyitic type), G: close-up of the peristoma, H: A fragment of the peripetal fasciole in D. brisenoi, showed by the arrow, I: Close-up of the unpaired ambulacrum showing the poriferous zones. 

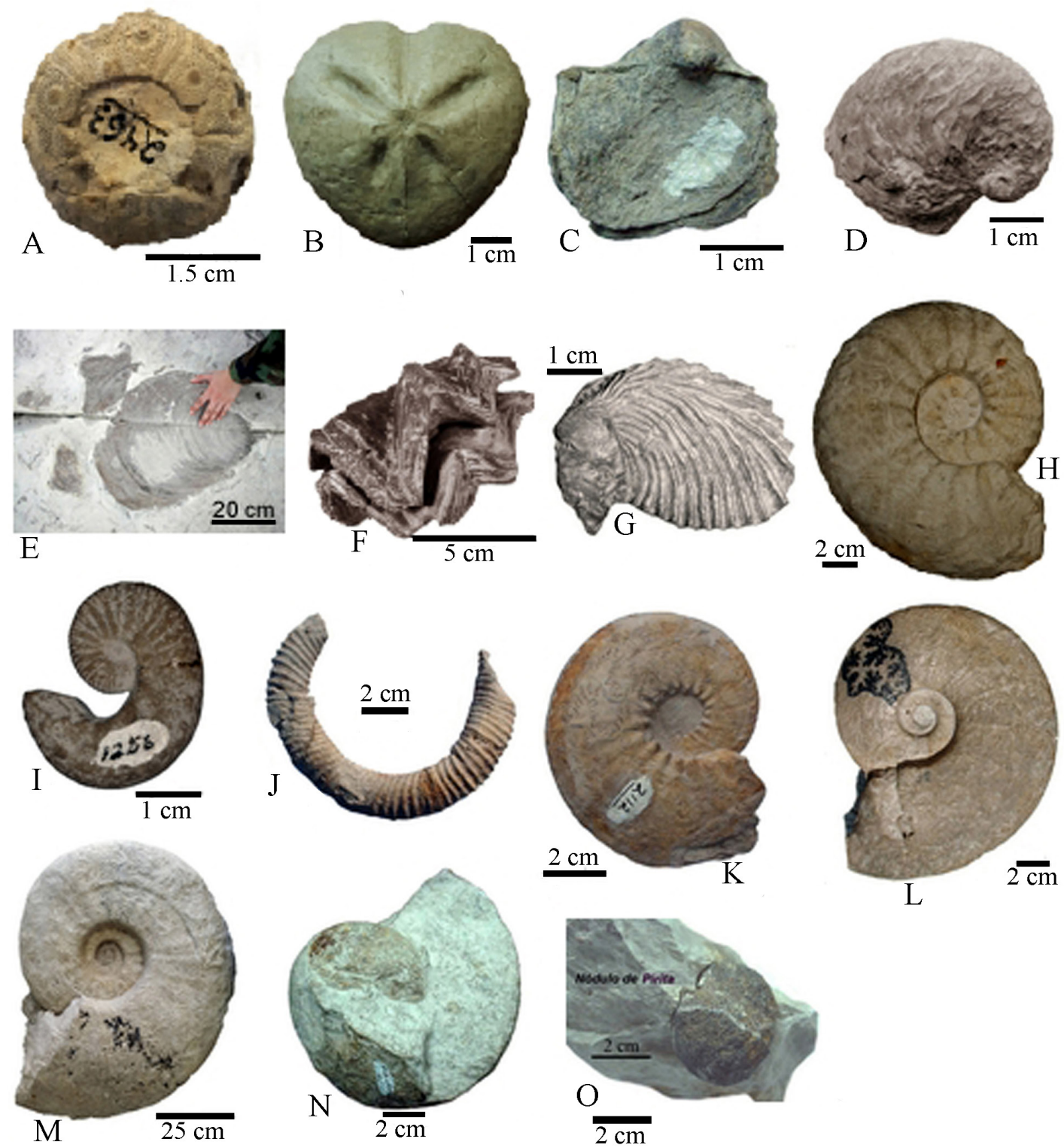

$10 \mathrm{~cm}$
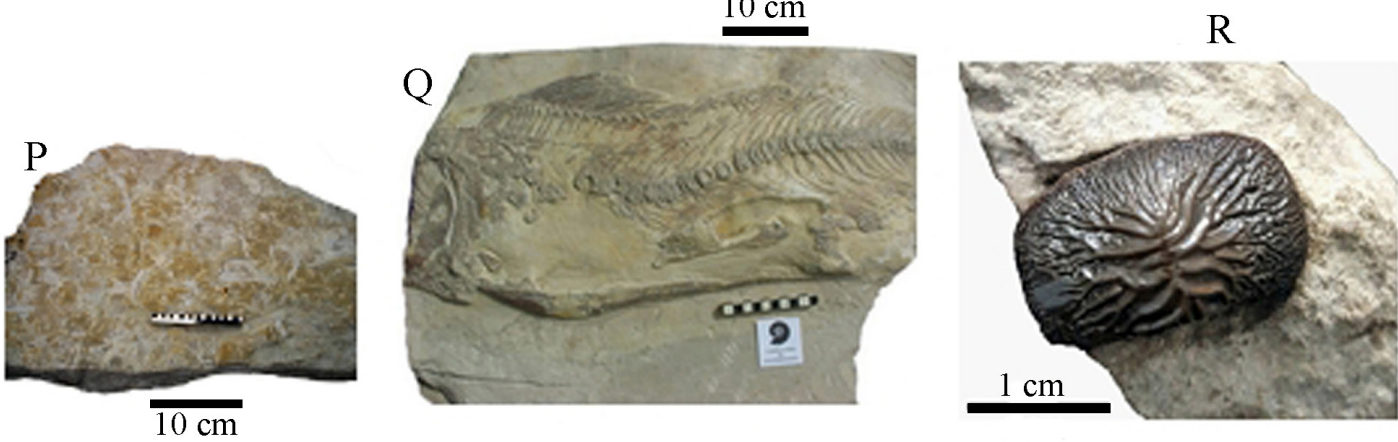

Figure 5 Associated fauna to Diplodetus brisenoi nov. sp. from Austin Formation in the study area. A: Cidaris texanus Clark, B: Micraster uddeni Cooke, C: Pycnodonte aucella Roemer, D: Exogyra ponderosa Roemer, E: Inoceramus undulatoplicatus Roemer, F: Lopha macoyi, G: Lopha travisana Stephenson, H: Pseudoschloenbachia mexicana (Renz, 1936), I: Scaphites hippocrepis (DeKay, 1828), J: Gliptoxoceras sp., K: Menabites (Delawarella) janneti (Young, 1963), L, M: Parapuzosia bosei, N: Eutrephoceras sp., O: Pyrite nodule, P: Ichnofossils (Thalassinoides), Q: Teleostean fish Goulmimichthys sp., R: Ptychodus sp. 


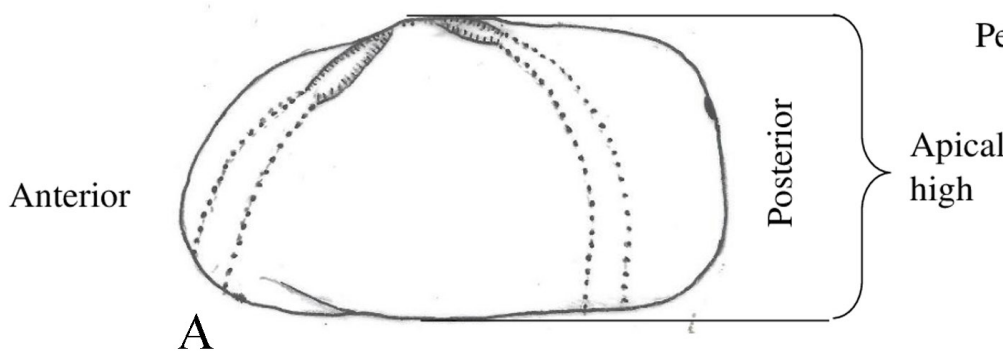

Sunken the scope

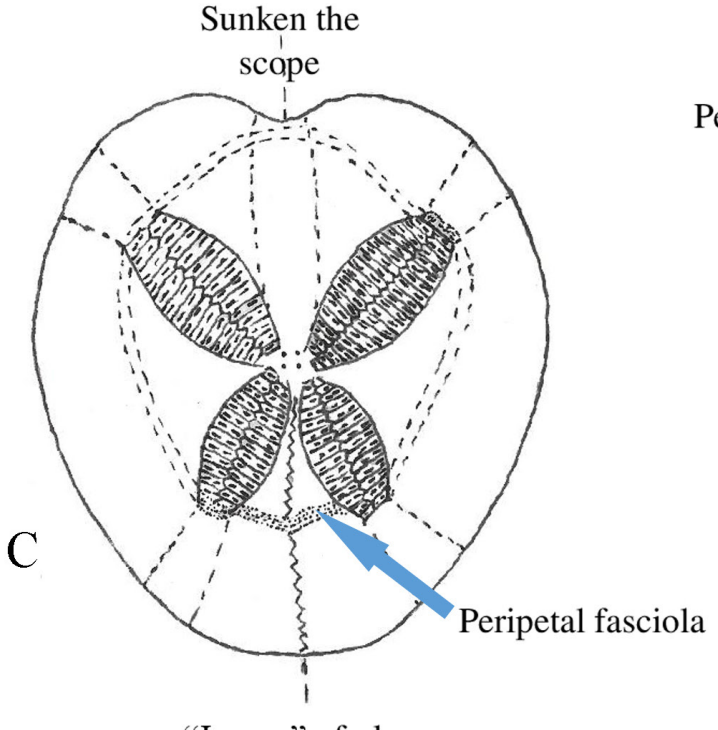

"Loven" of plan

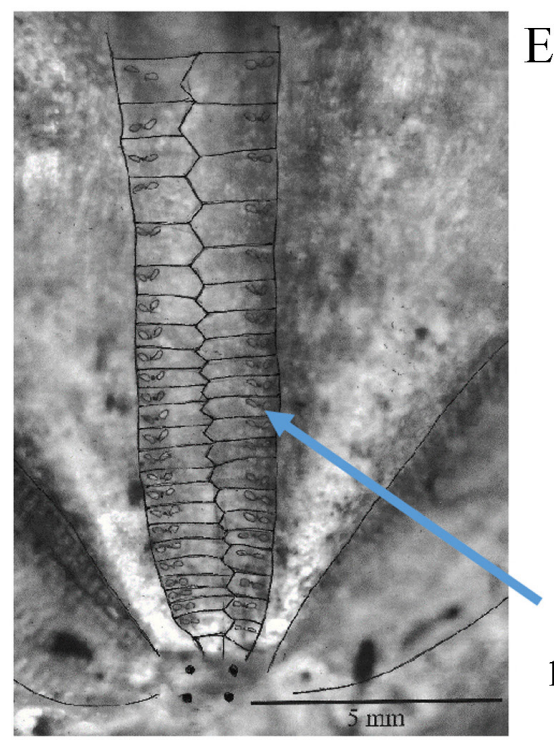

$\mathrm{E}$
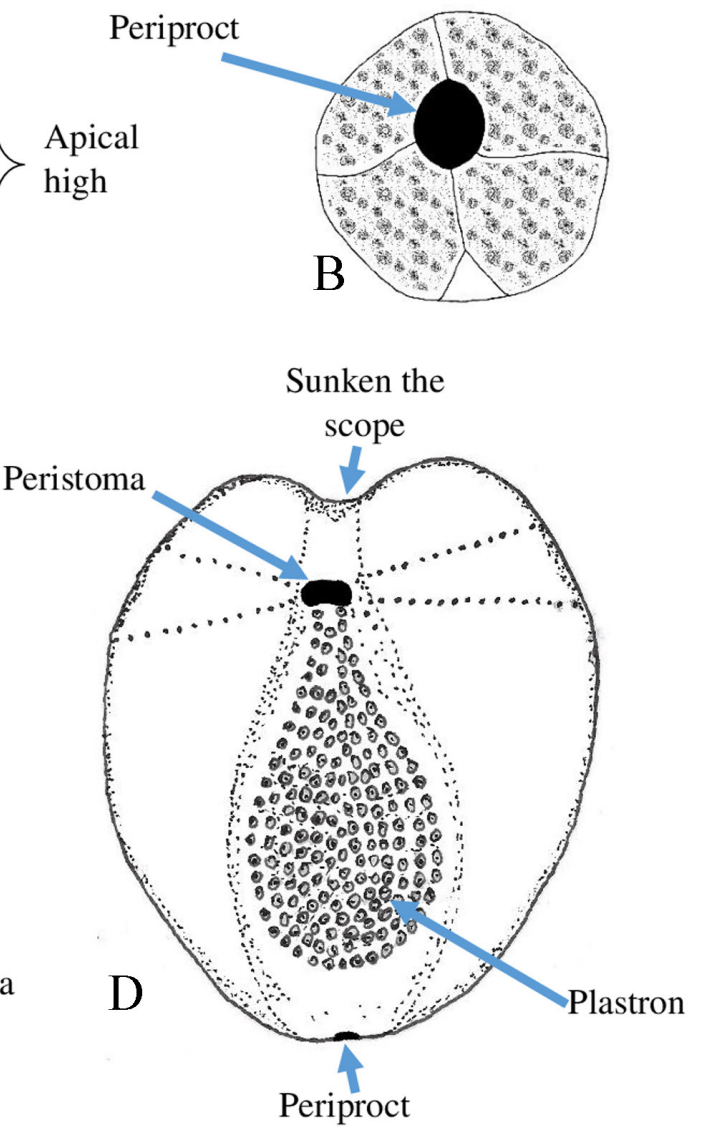

Sunken the

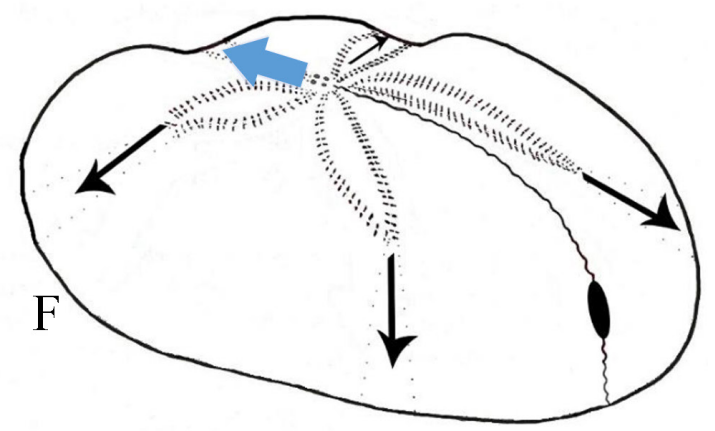

Unpaired ambulacrum present oval pores separated by a pair of granule.

Figure 6 Morphological characteristics Diplodentus brisenoi nov. sp. A: Line drawing showing the total height of the specimens of Diplodetus brisenoi nov. sp., B: Line drawing of the periprocal area showing the plates surrounding the periproct, C: Line drawing of the apical section showing the cordiforme morphology of Diplodetus brisenoi nov. sp. as well as the fragments of the peripetal faciole, D: Line drawing of the ventral section showing, the oval shape of the peristoma which is observed with a slightly extended edge and a groove that are forming the unpaired ambulacrum, E: Close-up of the unpaired ambulacra showing the ambulacral plates and pores in chevron, F:Line drawing diagram of Diplodetus brisenoi showing the direction of the movement (arrows) generated by the ambulacral tube feet in the process of cleaning and feeding the echinoid when it was completely or partially buried into the soft sediment. 


\section{Discussion}

The specimens reported in this work showing a combination of morphological characters that can easily differentiate from other species of the genus Diplodetus, and are therefore the support to consider Diplodetus brisenoi as a new species of echinoid (Table 1): medium size test, length between $35.5 \mathrm{~mm}$ to $36.4 \mathrm{~mm}$. Width between $32.0 \mathrm{~mm}$ and $32.4 \mathrm{~mm}$. Apical height from $20.1 \mathrm{~mm}$ to 21.1 $\mathrm{mm}$, oval, cordiform. Paired petaloids ambulacra, sunken in a deep furrow. Paired petals moderately sunken, the anterior pair is longer than the posterior, the first extends up to $2 / 3$ of the margin and portrays a divergent angle between 135 and 140 degrees, the posteriors are very close together, presents a divergent angle of 124 to 126 degrees (Figures 4D and 4H), peripetal fasciola present. In D. brevistella (Schlüter, 1899) the test is not as wide as long, shallow notch of the odd ambulacra is almost absent at area level, with a sub anal and peripetal fasciola. In D. americanus (Stephenson, 1941), the size of the test is considered as medium, reaching $57.0 \mathrm{~mm}$ of length, the unpaired petals are at superficial level, the paired petals show a divergent angle of 120 degrees in the anterior part and $55^{\circ}$ in the posterior part. In $D$. bucardium (Goldfuss, 1829) the test has a length of $55.0 \mathrm{~mm}$ and it is higher in the posterior part, with a cordiform outline. In D. duponti (Lambert, 1911), the size of the test reaches a minimum length of 60.0 $\mathrm{mm}$, the anterior margin is cut and shortened, the paired ambulacra present a divergent angle of $105^{\circ}, 1.5$ times more than the posterior. Taking in consideration D. coloniae (Cotteau, 1877), the outline of the test is more oval with the anterior scot light, the paired petals present a divergent angle of $140-150^{\circ}$.

Distribution of genus Diplodetus: Diplodetus has been widely reported in different localities of Europe, and in a more restricted distribution area in Africa and America (Fischer, 1966). This genus is reported during the Upper Campanian and Lower Mastrichtian in Belgium (Jagt, 2000) and for the Campanian in Spain (Rehfeld and Ernest,
1998). In the American continent, Diplodetus is also known for the Campanian of Texas.

Aside from Cretaceous rocks, the record of the genus is less common. It has been described in Paleocene rocks of Madagascar, Ukraine and Western Europe (Cotteau, 1877). The presence of D. brisenoi in northeastern Mexico, represent the only known record for the genus in Mexico (Silva-Martínez et al., 2014) and the second one in America, and it is also the most austral record for this continent (Figure 7).

Paleoecology and paleobiology of the genus Diplodetus: In the Northeastern of Mexico, the Austin Formation has been widely described by different authors at different localities (Shumard, 1860; Reeside, 1927; Adkins, 1930; Young, 1963; Carrasco, 1963, 1969; Taff, 1892; Santamaría-Zabala, 1991; Sohl et al., 1991; Eguiluz de Antuñano, 2001; Escalante et al., 2002; Romo-Ramírez et al., 2002; Santiago et al., 2003; Stinnesbeck et al., 2005; Myers, 2010; Silva-Martínez et al., 2014). It was deposited under conditions of an inner/medium continental shelf environment. The stratigraphic age for this unit was ranked from Coniacian to Lower Campanian (Silva-Martínez et al., 2014).

The Early Campanian was a time of transgressions that influenced the Northeastern of Mexico, it carried a major influx of terrigenous sediment into the Gulf of Sabinas (Sohl et al., 1991). This increment in the terrigenous input favored the formation of a soft-to hardseafloor, which make easier the establishment of benthonic biota (e.g. echinoderms).

In the study area, the presence of several groups of endobenthonic organisms such as serpulids and other unidentified burrowers, for ammonites, the kind of preservation displays internal moulds that, in addition to the presence of Diplodetus brisenoi, may evidence the presence of a soft seafloor. The genus Diplodetus, like other genera of the family Brissidae is characterized as detritivorous organisms that exhibit an endobenthonic behavior. This ecological adaptation was linked with the modification of the position of the peristoma and the periproct from the original Bauplan or "Loven plane" (Moore 
Table 1. Comparison chart of the different species of Diplodetus.

\begin{tabular}{|c|c|c|c|c|c|c|}
\hline SPECIES & $\begin{array}{l}\text { Diplodetus brevistella } \\
\text { (Schlüter, 1899) }\end{array}$ & $\begin{array}{l}\text { Diplodetus americanus } \\
\text { (Stephenson, 1941). }\end{array}$ & $\begin{array}{l}\text { Diplodetus bucardium } \\
\text { (Goldfuss, 1829). }\end{array}$ & $\begin{array}{l}\text { Diplodetus duponti } \\
\text { (Lambert, 1911). }\end{array}$ & $\begin{array}{l}\text { Diplodetus coloniae } \\
\text { (Cotteau, 1877). }\end{array}$ & Diplodetus brisenoi nov sp. \\
\hline 包 & $\begin{array}{l}\text { Sub-cordiforme, wider } \\
\text { than long. }\end{array}$ & Cordiforme. & Subcordiforme. & Subcordiforme. & Oval outline. & Strongly cordiforme. \\
\hline 눤 & $\begin{array}{l}\text { Medium size test. Length } \\
\text { between } 50 \text { to } 53 \mathrm{~mm} \text {. }\end{array}$ & $\begin{array}{l}\text { Cordiforme medium } \\
\text { sized. A minimum length } \\
\text { of } 57 \mathrm{~mm} \text {. }\end{array}$ & $\begin{array}{l}\text { Test slightly longer than } \\
\text { wider (until ca. } 55 \mathrm{~mm} \text { of } \\
\text { length). }\end{array}$ & $\begin{array}{l}\text { The test is not as } \\
\text { wide as long (more } \\
\text { than } 60 \mathrm{~mm} \text { ), with } \\
\text { the frontal notch, but } \\
\text { not too deep and the } \\
\text { posterior part is } \\
\text { truncated. }\end{array}$ & $\begin{array}{l}\text { Test as long as wide. } \\
\text { Length up to } 57 \mathrm{~mm} \text {. }\end{array}$ & $\begin{array}{l}\text { Medium size test, Length: } \\
\text { between } 35.5 \text { to } 36.4 \mathrm{~mm} \text {. } \\
\text { Wide at the area level, } \\
\text { between } 32 \text { and } 32.4 \mathrm{~mm} \text {. } \\
\text { Apical height of } 20.1 \text { to } 21.1 \text {, } \\
\text { and oval. }\end{array}$ \\
\hline 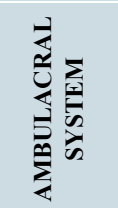 & $\begin{array}{l}\text { Adapically in a furrow } \\
\text { Ambulacra. }\end{array}$ & $\begin{array}{l}\text { Ambulacra matched } \\
\text { deeply sunk into a } \\
\text { groove. Petals almost the } \\
\text { same lenght. }\end{array}$ & $\begin{array}{l}\text { Ambulacra almost the } \\
\text { same size and in a deep } \\
\text { furrow. }\end{array}$ & $\begin{array}{l}\text { Paired ambulacra, in } \\
\text { a moderate furrow, } \\
\text { less depth than in } D \text {. } \\
\text { bucardium and } D \text {. } \\
\text { parvistella. }\end{array}$ & $\begin{array}{l}\text { Ambulacra in a } \\
\text { shallow groove or } \\
\text { absent. }\end{array}$ & $\begin{array}{l}\text { Petaloid-paired ambulacra } \\
\text { with pores in the fissure, the } \\
\text { paired petals have the same } \\
\text { size and shape to the posterior } \\
\text { ambulacra, which are short } \\
\text { and sunken in a deep furrow. }\end{array}$ \\
\hline 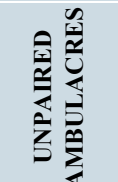 & $\begin{array}{l}\text { The anterior notch is } \\
\text { shallow or absent. }\end{array}$ & $\begin{array}{l}\text { Posterior petal inclined; } \\
\text { anterior ambulacra } \\
\text { practically at surface } \\
\text { level of the test. }\end{array}$ & $\begin{array}{l}\text { Frontal groove slightly } \\
\text { marked. Truncated } \\
\text { vertically on the back. }\end{array}$ & $\begin{array}{l}\text { Groove in the shallow } \\
\text { anterior margin. }\end{array}$ & $\begin{array}{l}\text { The anterior ambulacra } \\
\text { is cut out slightly on } \\
\text { the margin. Vertically } \\
\text { truncated posterior } \\
\text { part. }\end{array}$ & $\begin{array}{l}\text { The odd petal presents oval } \\
\text { pores separated by a pair of } \\
\text { granules. }\end{array}$ \\
\hline 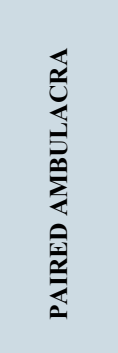 & $\begin{array}{l}\text { Paired petaloids } \\
\text { ambulacra with } \\
\text { elongated pores. }\end{array}$ & $\begin{array}{l}\text { Paired ambulacra deeply } \\
\text { sunken, divergent anterior } \\
\text { pair at } 120^{\circ} \text {, and } 1.5 \text { more } \\
\text { times than the posterior } \\
\text { pair (divergent at } 55^{\circ} \text { ). }\end{array}$ & $\begin{array}{l}\text { Petaloid Ambulacra } \\
\text { almost same size and in a } \\
\text { deep furrow, the anterior } \\
\text { pair presents a divergent } \\
\text { angle of } 100^{\circ}, 1.4-1.5 \\
\text { times more than the } \\
\text { posterior pair, with } \\
\text { elongated pores. }\end{array}$ & $\begin{array}{l}\text { Anterior petals } \\
\text { divergent in } 105^{\circ}, 1.5 \\
\text { times greather than } \\
\text { the posteriors, with } \\
\text { elongated rounded } \\
\text { pores. }\end{array}$ & $\begin{array}{l}\text { Paired petals slightly } \\
\text { different in length. } \\
\text { Petals pairs with a } \\
\text { divergent angle of } 140 \\
\text { - } 150 \text { degrees. }\end{array}$ & $\begin{array}{l}\text { Paired petals moderately } \\
\text { depressed, the anterior pair is } \\
\text { longer than the posterior pair. } \\
\text { The first extends two-thirds of } \\
\text { the way to the margin and } \\
\text { presents a divergent angle } \\
\text { between } 135 \text { and } 140 \text { degrees, } \\
\text { the posterior ones are close } \\
\text { together and present a } \\
\text { divergent angle of } 124 \text { to } 126 \\
\text { degrees. }\end{array}$ \\
\hline 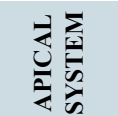 & $\begin{array}{l}\text { Etmophract type apical } \\
\text { system with four } \\
\text { gonopores. }\end{array}$ & $\begin{array}{l}\text { Apical system at the top } \\
\text { of the test. }\end{array}$ & $\begin{array}{l}\text { Not described by the } \\
\text { author. }\end{array}$ & $\begin{array}{l}\text { Not described by the } \\
\text { author. }\end{array}$ & $\begin{array}{l}\text { Ethmofract with four } \\
\text { gonopores. }\end{array}$ & $\begin{array}{l}\text { Semiethmolytic typeapical } \\
\text { system with four gonopores. }\end{array}$ \\
\hline 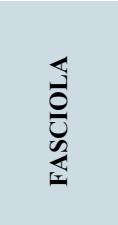 & $\begin{array}{l}\text { Subanal fasciola present; } \\
\text { peripetal fasciola } \\
\text { present, although } \\
\text { generally represented } \\
\text { only by a diffuse or } \\
\text { partial band of } \\
\text { granulations. }\end{array}$ & $\begin{array}{l}\text { Subanal fasciola, and } \\
\text { posterior peripetal well } \\
\text { developed. }\end{array}$ & $\begin{array}{l}\text { Subanal fasciola well } \\
\text { developed, Peripetal } \\
\text { fasciola is observed } \\
\text { bording the posterior } \\
\text { petals. }\end{array}$ & $\begin{array}{l}\text { Subanal fasciola well } \\
\text { developed, wide; } \\
\text { irregular peripetal } \\
\text { fasciola bording the } \\
\text { posterior petals. }\end{array}$ & $\begin{array}{l}\text { Subanal fasciola } \\
\text { present. }\end{array}$ & Peripetal fasciola present. \\
\hline
\end{tabular}

et al., 1966). Such characteristics are also well exposed in specimens of $D$. brisenoi, which confirms its detritivorous and endobenthonic behavior for this species. Also other endobenthonic organisms (e.g. serpulids) are able to bury themselves into the sediment (Figure 6F).

The occurrence of sedimentary pyrite in some strata of the Austin Formation in the study area (personal observation) suggests that during the deposition of the Austin Formation, there was a deficit in oxygen concentration, it makes possible the preservation of organic matter in the centimeters just below the sediment-water interface, in contrast to the water column, where the well oxygenated conditions promote the presence of epibenthonic fauna (Gryphaea, Exogyra, Lopha) and nektonic organisms such as fishes and ammonites. It seems that organic matter served as a food source to endobenthonic organisms. The specimens of $D$. brisenoi were able to process rich organic matter particles that serve as nutrients. The sediment was removed and captured through the 


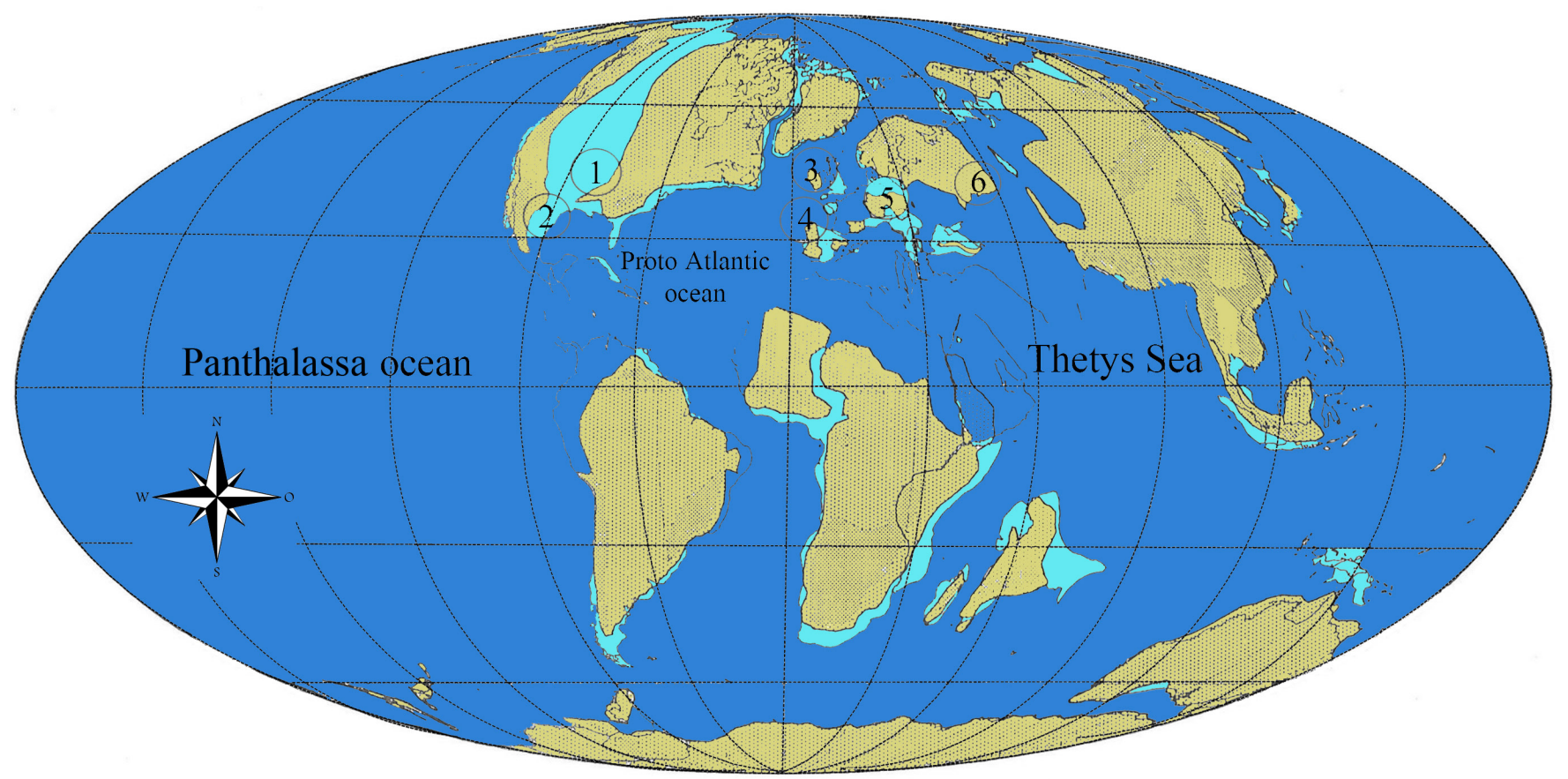

Figure 7 Paleogeographic map showing the distribution of the genus Diplodetus spp. during Early Campanian (Late Cretaceous). 1: $D$. americanus, Texas, USA, 2: D. brisenoi nov. sp., Jiménez, Coahuila, Mexico, 3: $D$. parvistella, D. americanus, $D$. bucardium. Netherlands, 4: Diplodetus parvistella, D. bucardium, Belgium, 5: Diplodetus brevistella, Germany, 6: Diplodetus coloniae, Ukrania. Paleogeographic map modificated from Smith et al. (1994).

ambulacral feet, and moved through the fasciole to the peristome.

It seems that a continental shelf scenario, with a soft seafloor and the organic matter in the sediment made easier the presence of detritivorous organisms in the study area, such as several genera of echinoids, the specimens of $D$. brisenoi, serpulid worms and other burrowers.

\section{Conclusion}

The description of three echinoids specimens of the genus Diplodetus reported by Silva-Martínez et al. (2014) from the Lower Campanian Austin Formation (Upper Cretaceous), shows significative morphological differences with $D$. brevistella, $D$. americanus, D. bucardium, D. duponti and D. coloniae therefore Diplodetus brisenoi nov. sp., must be considered as a new echinoid species from the Austin Formation (Lower Campanian), from the Mexican state of Coahuila, northeastern Mexico.
Continental shelf environments, the presence of soft seafloor, and organic matter in the sediment, which represent a food source for endobenthonic organisms, are the main features that define a scenario that contribute to the developement of detritivore organism, such as D. brisenoi in the Austin Formation of northeastern Mexico.

\section{Acknowledgements}

The authors are deeply grateful to Anabel Herrera Aguirre (UANL) and Claudia Mendoza (Canada) for their observations of the English version of this manuscript. Special thanks go to Dra. Blanca Estela Buitrón-Sánchez (UNAM) and M.C. Andrés Ramos-Ledezma (UANL) for reviewing the manuscript. Financial support for field work was provided by the Programa de Apoyo a la Investigación Científica y Tecnológica (Paicyt), Proyecto $\mathrm{N}^{\circ}$ GN1181-11. 


\section{References}

Adkins, W.S., 1930, Texas Comanchean Echinoids of the genus Micraster: University of Texas, Bulletin, 3001, 101-120.

Boule, M., 1899, Note sur de nouveaux fossiles secondaires de Madagascar: Bulletin du Muséum d'Histoire: Naturelle, 5, 130-134.

Carrasco, B.V., 1963, Estratigrafía de la parte Superior del Grupo Austin en Jiménez Coahuila (México): Revista del Instituto Mexicano del Petróleo, 1(2), 18-25.

Carrasco, B.V., 1969, Amonitas del Campaniano Inferior del Norte de Coahuila: Sociedad Geológica Mexicana, 30(2), 144-151.

Cotteau, G., 1877, Description des Echinides, in Locard, A. (ed.), Description des Faunes des terrains Tertiaires moyens de la Corse: Annales de la Société d'Agriculture, Histoire Naturelle et Ars Utiles de Lyon, Paris \& Genève, 227-335

Cotteau, G., 1908, Paléontologie de Madagascar; 6. Les échinides: Annales de Paléontologie 3,145-188.

DeKay, J.E., 1828, Report on several fossil multilocular shells from the state of Delaware: With observations on a second specimen of the new fossil genus Eurypterus: Annales of the Lyceum of Natural History, 2, 273-279.

Eguiluz de Antuñano, A.S., 2001, Geologic Evolution and Gas Resources of the Sabinas Basin in North-eastern Mexico, in Bartolini, C., Bluffer, R.T., Cantu-Chapa, A. (eds.), The western Gulf of Mexico Basin Tectonics, Sedimentary Basins, and petroleum systems: AAPG Memoir, 75, 241-270.

Escalante, M.J.G., Rocha, R.M., Chiapa, G.R.R., Bastida, J.R., 2002, Carta Geológico-Minera Ciudad Acuña, H14-7, Escala 1:250000: Estado de Coahuila, Informe técnico.

Fischer, A.G., 1966, Spatangoids, in Moore, R.C. (ed.), Treatise on Invertebrate Paleontology, Part U, Echinodermata 3, 2. - Geol. Soc. Am., Boulder/Univ. Kansas Press, Lawrence:
U543-U628.

Goldfuss, A., 1829, Petrefacten Deutschlands und der angranzenden Lander: Düsseldorf.

Gray, J.E., 1855, An arrangement of the families of Echinida, with descriptions of some new genera and species: Proceedings of the Zoological Society London, 23, 35-39.

Jagt, J.W.M., 2000, Late Cretaceous-Early Paleogene echinoderms and the K/T boundary in the southeast Netherlands and northeast Belgium. Part 4. Echinoids, Scripta: Geologica, 121, 181-375.

Lambert, J., 1911, Description des Échinides crétacés de la Belgique principalement de ceux conservés au Musée royal de Bruxelles. II. Échinides de l'étage Sénonien: Mémoires du Musée Royal d'Histoire Naturelle de Belgique, 4: 1-81, pls 1-3.

Moore, R.G., 1966, Treatise on Invertebrate Paleontology: Geological Society of America and University of Kansas Press, Volume L, 429-434.

Morton, S.G., 1841, Descriptions of two new species of fossils from the Lower Cretaceous strata of New Jersey: Proceedings of the Academy of Natural Sciences of Philadelphia, 1, 131-132.

Myers, T.S., 2010, Earliest occurrence of the Pteranodontidae (Archosauria: Pterosauria) in North America; New material from the Austin Group in Texas: Journal of Paleontology, 84(6), 1071-1081.

Newman, M.C., Ownby, D.R., Mezin, L.C.A., Powell, D.C., Christensen, T.R.L., Lerberg, S.B., and Anderson, B.-A., 2000, Applying species-sensitivity distributions in ecological risk assessment: assumptions of distribution type and sufficient number of species: Environmental Toxicology and Chemistry 19, 508-515.

Reeside, B.J., 1927, The Cephalopods of the Eagle Sandstone and Related Formations in the Western Interior of the United States: United States Government Printed office, Professional Paper 151, 23 p. 
Rehfeld, U., Ernst, G., 1998, Hydrozoan build-ups of Millepora irregularis sp. nov. and fungiid coral meadows of Cunnolites Alloiteau (Anthozoa)palaeoecological and palaeoceanographical implications for the Upper Cretaceous of north Cantabria (northern Spain), Facies 39, 125-138.

Renz, O., 1936, Stratigraphie und mikropaläontologische Untersuchung der Scaglia (Obere Kreide-Tertiär) im zentralen Apennin: Ecoglae geologicae Helvetiae, 29, $1-149$

Romo-Ramírez, J.R., Herrera-Monreal, J.C., Rodríguez-Rodríguez, J.S., 2002, Carta Geológico-Minera San Miguel H13-12, escala 1:250000: Pachuca, Hidalgo, México, Consejo de Recursos Minerales, informe, 64 p.

Santamaría-Zabala, R., 1991, Ammonoideos del Cretácico Superior de la Plataforma NordCastellana y parte de la Cuenca NavarroCántabra. Paleontología y Bioestratigrafía: Universidad Autónoma de Barcelona, Barcelona, Tesis Doctoral, 375 p.

Santiago, C.B., Herrera-M.J.C., Ontiveros, E.E., Martínez, R.L., 2003, Carta GeológicoMinera Piedras Negras, H14-10, Escala 1:250000: Estado de Coahuila y Chihuahua, Informe técnico.

Schlüter, C., 1899, Ueber einige von Goldfuss beschriebene Spatangiden. II: Stück. Zeitschrift der deutschen geologischen Gesellshaft, 51, 104-124, pls. 9-10.

Schlüter, C., 1900, Ueber einige Kreide-Echiniden. Zeitschrift der deutschen geologischen Gesellschaft, 52, 360-379, pls. 15-18.

Shumard, B.F., 1860, Descriptions of new Cretaceous fossils from Texas: Transactions of the Academy of Science of the Saint Louis, 1, 590-610.
Silva-Martínez, L.E., Blanco-Piñón, A.,de LeónGonzález, J.A., 2014, Equinoideos del Cretácico Tardío del Norte de Coahuila, México: Boletín de la Sociedad Geológica Mexicana, 66 (2), 377-395.

Smith, A. G., Smith, D.G., Funell, B.M., 1994, Atlas of Mesozoic and Cenozoic Coastlines: Cambridge University Press, Cambridge, 99 p.

Sohl, N.F., Martinez, E., Salmeron-Urena, P., Soto-Jaramillo, F., 1991, Upper Cretaceous, in Salvador, A. (ed.), The Gulf of Mexico basin: Geological Society of America, The Geology of North America, J, 205-244.

Stephenson, L.W., 1941, The larger invertebrate fossils of the Navarro Group of Texas (exclusive of corals and crustaceans and exclusive of the fauna of the Escondido Formation). - Texas Univ. Bull., 4101: 1-641, pls. 1-95.

Stinnesbeck, W., Ifrim, C., Schmidt, H., Rindfleisch, A., Buchy, M-C., Frey, E., González-González, A., Vega, F.J., Cavin, L., Keller, G., Smith, K.T., 2005, A new lithographic limestone deposit in the Upper Cretaceous Austin Group at El Rosario, County of Múzquiz, Coahuila, northeastern Mexico: Revista Mexicana de Ciencias Geológicas, 22(3), 401-418.

Taff, B.J., 1892, Reports on the Cretaceous area north of the Colorado River: Annual Report of the Geological survey of Texas, 3, 267-379.

Vega, F.., Garassino, A., Zapata-Jaime, R., 2013, Enoploclytia tepeyacensis n. sp. (Crustacea, Decapoda, Erymidae) from the Cretaceous (Campanian) of Coahauila, NE Mexico: Boletín de la Sociedad Geológica Mexicana, 65(2), 207-211.

Young, K., 1963, Upper Cretaceous Ammonites from the Gulf Coast of the United States, University of Texas Publication, 6304, 48-123. 